\title{
Equality and Advantage in Emerging Federations and the Dilemma of Non-Renewable Natural Resources
}

\author{
The Cases of the Solomon Islands and Trinidad and Tobago
}

Nico Steytler

$1 \quad$ Introduction

In many fragmented societies, where identifiable groups are clustered in distinct territorial areas, conflict often revolves around ownership, control and access to the benefits of non-renewable natural resources (NRNR s), particularly when it concerns the highly lucrative resources of oil and gas, which are usually very unevenly spread across a country. A World Bank report even claims that this is one of the most important causes of civil war. ${ }^{1}$ In the case of South Sudan, the current civil war appears to be driven by the struggle for control of oil resources. The splitting up of provinces by the Kirr regime, in violation of a peace agreement, was to ensure that the oil-producing areas would not fall under the jurisdiction of the provinces controlled by ethnic groups other than his Dinka community. ${ }^{2}$ The acquisitive urge of political elites to benefit from NRNRs is usually clothed in the garb of interests organised around language, culture, ethnicity, religion, clans, and so forth.

In many fragile countries, federalism is seen as the last resort to address conflict, as the centralised state is seen as the very reason for the conflict in the first place. The centralisation of power has led to inequality and the marginalisation of minority groups. The failure of the centralised state to be a redistributor of resources across the nation becomes most obvious when natural

1 Nicholas Haysom and Sean Kane, "Negotiating Natural Resources for Peace: Ownership, Control and Wealth Sharing," Briefing Paper (October 20o9): 20 footnote 9, http://comparativeconstitutionsproject.org/files/resources_peace.pdf.

2 See Zemelak Ayitenew Ayele, “Constitutionalism: The Missing Element in South Sudan's Elusive Quest for Peace through Federalism?," in Decentralisation and Constitutionalism in Africa, eds. Charles Fombad and Nico Steytler (Oxford: Oxford University Press, 2019), $234-254$. 
resources are monopolised by the elite (most often from a particular group) to the exclusion of the country as a whole, often exacerbating inequality and the marginalisation of producing regions.

As a conflict resolution mechanism, federal arrangements for such countries are confronted with two contradictory objectives: self-government for minority or marginalised groups, and at the same time, solidarity between subnational governments in the sense that there is an equality of citizenship, including access to equivalent public services, irrespective of their location.

When natural resources become part of the controversy (or are the controversy) the tension between self-government and solidarity intensifies. If the emphasis is on self-government, the control and benefits of NRNR S are claimed by the group on whose territory they are found; the claim is seen as an essential part of self-government and thus of federalism itself. Where solidarity is the more prominent impulse, NRNR $s$ are deemed to be the patrimony of the country as a whole, the benefits of which are to be fairly shared by both the national and subnational governments alike. Whereas solidarity leads to more equal outcomes, a self-government approach to NRNR s may result in inequality.

The dilemma is then how this tension between self-government and solidarity is managed: is equality among subnational governments pursued or are producing regions allowed to keep the advantages of NRNRs? Where selfgovernment (or a measure thereof) over NRNR $s$ is accepted, possibly leading to inequality, how are regional claims to superior access to such resources justified? Conversely, how is such advantage or inequality tolerated by the regions less endowed or the polity in general?

In practice, management of the tension between self-government and solidarity hovers between two extremes. At the one end of the spectrum, NRNR $s$ are seen as a component of self-government, the benefits of which accrue to subnational governments. At the other end, NRNR s, regarded as the nation's patrimony, fall under central government's control, but revenue derived from such resources is shared among all levels of government. Within this spectrum one finds the partial recognition of claims of oil producing subnational governments (SNG s), for a higher share of oil revenue than others which have no such bounty. The justifications for arrangements that lean towards self-government and giving the producing SNG s a greater share in natural resources wealth, include 'fend-for-yourself' federalism, corrective measures to compensate for damage caused by the extraction of the resource, and historical land owing regimes.

This chapter examines the question with reference to two countries on opposite sides of the globe - the Solomon Islands and Trinidad and Tobago. They have been chosen because both island states are currently debating a possible 
non-centrist future: in the case of the Solomon Islands, a fully-fledged federation, while in Trinidad and Tobago an autonomy status for Tobago is being considered. In both countries, the discussions are grounded by draft constitutional texts. Furthermore, NRNR s are on the constitutional negotiating table with oil and gas a focal area. Although oil and gas are exploited in Trinidad and Tobago, the discovery of such riches is still but a hope in the Solomon Islands. However, in both cases the question of equality and advantage are firmly on the agenda.

The chapter is organised in three parts. Section 2 sets out the broad issues with regard to the drivers of self-government and solidarity, the ownership, control and benefit of NRNR s, and the approaches in practice to the question of equality and advantage. Section 3 examines the proposals for self-government and the management of NRNR $s$ in the Solomon Islands and in Trinidad and Tobago. Section 4 contains concluding remarks.

The management of NRNR s reveals an inherent tension in the federal system tension between the objectives of self-government and solidarity. Where the emphasis falls on self-government, SNG s usually have a greater say over ownership, control and the financial benefits of NRNR s. Where the focus is on solidarity, NRNRs are seen as a national asset and the federal government must see to the equitable distribution of revenue through an equalisation system. Where the SNG s are in control of NRNR s (which are mostly unevenly spread), inequality among SNG $\mathrm{s}$ is more likely to prevail, while when the federal government is in charge, equalisation is the most likely outcome.

\subsection{Drivers of Self-Government and Solidarity}

In conflict ridden societies, the fight by territorially based groups for decentralisation is most often driven by the quest for equal citizenship (including equal access to public services) and self-government. The first seeks equitable access to the wealth of the nation, while the latter demands access to sufficient revenue resources to enable self-government.

Inequality between people living in one region compared to others can be measured by various indicators such as relative poverty levels, literacy rates, infant mortality rates, life expectancy, and so forth. ${ }^{3}$ Often these indicators are proxies of state action or inaction. The per capita state expenditure across

3 See Peter Wanyande, "Devolution and Territorial Development Inequalities: The Kenyan Experience," Working Paper Series, no. 187 (2016). 
regions can vary significantly, resulting in unequal levels of services (health, education, social development), economic development and infrastructure (roads, water, sanitation). Even if the per capita spending is the same across regions, historical backlogs in previously marginalised regions may prevent any catching up with other more well-off regions.

Inequality flows from various factors including political, social, economic and natural reasons. For narrow political reasons, a regime may marginalise regions that fall in an opposition camp. ${ }^{4}$ Where economic development is concentrated around the capital, regions on the periphery suffer under-development. The unequal distribution of natural resources (water, arable land, minerals, and oil and gas) also affects levels of economic development and living standards.

In diverse societies such inter-regional inequality may be coloured by practices and perceptions of marginalisation and discrimination on the basis of identity markers, such as ethnicity, language, race, custom or religion. In many developing countries this sense of inequality often drives quests by territoriallybased groups for autonomy; apart from sentiments for the preservation of language, custom or religion, the notion of being treated as equal citizens through equitable development often lies at the heart of the quest for decentralisation. The centralised government is seen as serving a narrow partisan group, which results in the lived experience of material inequality with regard to access to basic state services, government jobs, and overall development. ${ }^{5}$ The quest for decentralisation is thus for equality of outcomes, shifting the focus to obtaining an equitable slice of the nationally raised revenue including that derived from NRNRs.

But the quest goes further; self-government is the other goal which seeks to control the territorial space occupied by the group. NRNR $\mathrm{s}$ are thus seen as assets of the region to be owned and controlled by the subnational government of the region, also enjoying the financial revenue flowing from such assets.

\subsection{Ownership, Control and Revenue of Non-Renewable Natural Resources}

The constitutional management of natural resources usually entails three dimensions: (1) who owns the resources; (2) who controls the resources; and (3) who benefits from the revenue generated by their exploitation. ${ }^{6}$ These

$4 \quad$ Wanyade, "Devolution,".

5 Wanyade, "Devolution,".

6 See Forum of Federations, "Oil and Gas in Federal Systems," forumfed.org (2014), https:// www.shareweb.ch/site/DDLGN/Documents/OIL\%2O_\%2oGAS\%2oin\%2ofederal\%2o countries\%2O(2014)_G\%20Anderson.pdf. This paper is based on George Anderson, Oil and Gas in Federal Countries (Oxford: Oxford University Press, 2013), which was the result 
questions are mostly interlinked: 'ownership' often also entails management, but federal 'ownership' does not necessarily imply that producing regions do not benefit more from the revenue than the other regions.

The regulation of NRNR $\mathrm{S}$ has become so important that in more recent constitutions the sharing of revenue from such resources is dealt with separately from the other revenue sharing provisions. ${ }^{7}$ As Haysom and Kane argue, where the conflict was driven by disputes of control and access to natural resources, these issues should lie at the heart of a peace-making constitution. ${ }^{8}$

As far as ownership is concerned, two trends are discernible. The first is that the federal government owns the resources on the basis that they are the national patrimony belonging to the nation as a whole. Examples of this trend are found in Brazil, Mexico, Venezuela, and Nigeria. The second trend is that the producing SNG s exercise 'ownership', with examples coming from Argentina, Australia, Canada and India. In the latter trend, the demarcation of a producing SNG's boundaries becomes important where the resource lies offshore. In most countries such resources belong to the federal government, ${ }^{9}$ but subnational boundaries may be drawn differently. A country's territorial waters of up to 12 nautical miles from the low water mark could be placed under the jurisdiction of the coastal SNG s (as in Argentina) or a lesser area (as in the USA - mostly three nautical miles). Anderson reports that in the Exclusive Economic Zone (EEZ; up to 200 nautical miles) the federal government has control over all economic resources, such as the exploitation of marine life, minerals, and oil and gas. ${ }^{10}$

'Ownership' usually also means the management of the resource, but not always. ${ }^{11}$ Management includes the issuing of licences for exploration and the extraction of the resource, and the taxing of such activities. ${ }^{12}$ However, the issuing of mining or exploration licences by, say, the federal government may have to contend with a SNG's powers, including those relating to land use and environmental protection.

of a 3-year comparative knowledge exchange project run by the Forum of Federations as part of its sectoral work.

7 Haysom and Kane, "Negotiating Natural Resources," 5.

8 Haysom and Kane, "Negotiating Natural Resources," 7.

9 Giorgio Brosio and Raju Jan Singh, "Raising and Sharing Revenues from Natural Resources:A Review of Country Practices," Discussion Paper, MFM Global Practice, no. 5 (August 2015): 11.

10 Forum of Federations, "Oil and Gas," 5.

11 Forum of Federations, "Oil and Gas", 2.

12 Forum of Federations, "Oil and Gas", 2. 
Separate from, but related to, the questions of who 'owns' or manages a resource, is the sharing of revenue that accrues from taxation and other fiscal instruments. Revenue is raised by either the federal government or SNG s (or both) through licences, royalties, corporate income tax, land use fees, etc. Both ownership and access to revenue are matters often regulated in a constitution. Where the federal government owns the resource, and raises revenue through different fiscal instruments, a number of approaches to sharing that revenue are observed in practice. First, such revenue may become part of the federal consolidated fund from which equitable transfers are made to each SNG. This is usually the case with revenue generated offshore. Secondly, in terms of a derivation principle, an additional amount is allocated to the producing SNG in terms of an agreed upon formula. ${ }^{13}$ For example, in Nigeria $13 \%$ of oil revenue goes to the producing states, while in Brazil that percentage differs according to the type of revenue source. Brazil is also an exception in that revenues accruing from off shore natural resources are reserved for the federal government. ${ }^{14}$ Where the SNG is the 'owner' or manager of the resource, revenue may accrue to the SNG or be shared with other SNG s, but also take into account the derivative principle.

\subsection{Approaches to Resource-Rich SNG $s$}

As the uneven distribution of NRNRS may lead to inequality among SNGS, various approaches are evident in dealing with the matter. These approaches reflect the interest of the different parties; the federal government may view all NRNR $S$ as the patrimony of the nation, a view shared by non-producing SNG S. The resource-rich SNG s may, on the other hand, emphasise their ownership of such resources and entitlement to the revenue flowing from such resources.

\subsubsection{Shared Resources - Equalisation}

The argument advanced by federal governments (and non-producing SNG s) is that natural resources must be seen as part of 'a national heritage', the proceeds of which are 'important in the financing of equal services and development nationwide, rather than [being] regional resources. ${ }^{\prime}$ This argument is the strongest when the resource extraction takes place off-shore; no SNG has a direct link to such resources. ${ }^{16}$

13 Andrew Bauer et al., Natural Resource Revenue Sharing (Natural Resource Governance Institute (NRGI) and the United Nations Development Programme (UNDP), 2016).

14 Brosio and Singh, "Raising and Sharing Revenues,".

15 Haysom and Kane, "Negotiating Natural Resources," 5.

16 Brosio and Singh, "Raising and Sharing Revenues," 11. 
However, despite this intention, the sharing of resource revenue is often not equitable. Inequality persists because the marginalised communities in producing SNG s do not benefit from the natural resources derived from the area in which they are settled. ${ }^{17}$ The revenue so collected is at best distributed equitably among all the regions, at worst (and most often) to the political dominant elites or regions. ${ }^{18}$ However, where the object is total equality (and is achieved), Ahmad and Brosio remind us, that this may lead to the evaporation of the very purpose of having a decentralised system. ${ }^{19}$

In response, marginalised regions demand greater control of and benefit from the natural resources in their areas. As noted above, where such marginalisation is based on discrimination on the basis of culture, language, custom, or religion (or a combination of these), conflicts most often follow. The quest is then for the region to own the natural resources, control their exploitation, and be the main beneficiary of revenue flowing from such exploitation.

The argument for this demand is two-fold: the first is that revenue should simply follow ownership, while the second argument is that the producing region must get a larger slice of the cake than others in order to compensate it or an indigenous community for the cost of exploitation, including environmental damage caused by it. ${ }^{20}$

\subsubsection{Arguments for Sole Access}

Producing SNGs argue for the retention of the benefits accruing from such resources even though this may lead to inequality. Two interlinked arguments are put forward in justification: the first is that the benefits of the resources follow 'ownership', and the second is that inequality is an inevitable consequence of federalism.

The demand for sole benefit is based, according to Haysom and Kane, on 'strong feelings of local community ownership over [natural resources] development and the resulting revenues.' ${ }^{21}$ When it comes to ownership of natural resources, they observe that 'emotional concerns can override fiscal

17 Bauer et al., Revenue Sharing, 9 .

18 Haysom and Kane, "Negotiating Natural Resources," 20.

19 Ehitisham Ahmad and Giorgio Brosio, "Can Lessons from Equalisation Transfers in Industrialised Countries be Applied to Reforms in Emerging-Market Countries?," in Comparing Fiscal Federalism, eds. Alice Valdesalici and Francsco Palermo (The Hague: Brill/Nijhoff, 2018), 169-189, 192.

$20 \quad$ Haysom and Kane, "Negotiating Natural Resources," 24.

21 Haysom and Kane, "Negotiating Natural Resources," 5. 
rationality'. These concerns may be labelled as 'emotions', which turn into 'feelings', to culminate in 'desires', but they become politically significant; the communities expressing these concerns may become 'secessionistprone areas' which then require special measures to prevent a secessionist conflict. $^{22}$

The first and most profound cause of the conflict is then the contestation over 'ownership'. Often it is a case of a regional polity wanting to 'take back' resources that have been exploited by the centre. The sentiment that natural resources are 'theirs' are often bound up in strong sentiments of identity politics and the quest for autonomy. The 'emotions' are fuelled, first, by a historical sense of injustice of past financial marginalisation ('this is payback time'); and secondly, compensation for damages caused by exploitation from which they did not benefit. Above all, it would seem that the notion of the NRNR $s$ being an incident of land ownership or occupation is a powerful driver, backed up by a community's view of itself being distinctive from the others (and the usual cleavages of ethnicity, race and religion which may apply). Such identity is tied with a sense of place, and attachment to land since time immemorial, where land and culture are intimately intertwined.

Linked to the notion of ownership, is a mode of federalism that has been described, with reference to the USA, as 'fend-for-yourself' federalism. ${ }^{23}$ Based on a culture of 'rugged state-individualism', where no equalisation system applies, inequality between states is tolerated on the basis that each state, legally equal to the other, must look after its own well-being. If one state has the fortune to be better endowed resource-wise, leading to inequality among SNG s, that is merely a consequence of federal self-rule. The consequence has been that in the USA, oil and gas rich states, retaining a larger percentage of revenue, have been able to provide better services than lower income, resource-poor states. ${ }^{24}$

\subsubsection{Compromises}

Between the two positions compromises are often struck in practice, allowing some extra benefit for the producing SNG S. As Ahmad and Brosio argue, some trade-offs need to be made between keeping a country together through

\footnotetext{
22 Haysom and Kane, "Negotiating Natural Resources," 17.

23 Elizabeth Alber, "Intergovernmental Financial Relations: Institutions, Rules and Praxis," in Comparing Fiscal Federalism, eds. Alice Valdesalici and Francesco Palermo (The Hague: Brill/Nijhoff, 2018), 223-273, 233.

24 Bauer et al., Revenue Sharing, 15.
} 
sharing natural resources but allowing some differences to meet self-rule impulses. ${ }^{25}$ Haysom and Kane also remark that a high degree of autonomy can lead 'to concerns regarding the unequal provision of public services between provinces (as in Canada), disparate levels of development (as in the United Arab Emirates) or may even spark the resentments which could provoke new sources of conflicts in divided societies.' ${ }^{26}$ They then ask '[h]ow will a minimum standard of public services be ensured across states and provinces, if resource wealth is trapped in one region only?'27

Compromises must be struck and as the matter goes to the heart of federal arrangements, it is best settled in the federal compact - the constitution. As Haysom and Kane write: '[C]onstitutions may be called upon to balance the competing feelings of community ownership over local resources against equally strong assertions that the wealth of the country belongs to all. ${ }^{28}$ A constitutional compromise is to entrench the derivation principle mentioned above; Nigeria is a clear example of providing $13 \%$ of resource revenue allocated to producing states, although it has not yet resolved the conflict in the Niger delta.

The justification of the unequal benefit from NRNR $s$ is that it serves as compensation for the environmental and social damage caused by the extractive industries. The latter may include loss of livelihoods, displacement of communities, and the attraction of migrants. ${ }^{29}$ Economists such as Brosio and Singh would argue that the amount of the compensation should then reflect as closely as possible the extent of the damage. ${ }^{30}$ The compensation rationale is thus no more than seeking to achieve equality among SNG s, making sure that a producing SNG is not prejudiced by the process of extraction. Arguments are also raised that the damage should be seen against a long-term horizon; in the case of NRNR s, the producing regions may be worse off after the depletion of the resource. ${ }^{31}$

\footnotetext{
25 Ahmad and Brosio, "Can Lessons from Equalisation Transfers be Applied?," 181.

26 Haysom and Kane, "Negotiating Natural Resources," 24.

27 Haysom and Kane, "Negotiating Natural Resources," 15.

28 Haysom and Kane, "Negotiating Natural Resources," 21.

29 Bauer et al., Revenu Sharing, 24.

$30 \quad$ Brosio and Singh, "Raising and Sharing Revenues," 3.

31 André Lecours and Daniel Béland, "Federalism and Fiscal Policy: The Politics of Equalization in Canada," Publius: The Journal of Federalism 40, no. 4 (Autumn 2010): 569596,585 .
} 
The question of SNG s' relationship to NRNR S and inequality has come to the fore in two countries composed of islands - Solomon Islands and Trinidad and Tobago. In both countries, interest groups, speaking on behalf of the component islands (in the latter case, only from one), have put forward constitutional drafts that seek to establish a federal system in the Solomon Islands and an autonomy status for Tobago. Included in the proposals are provisions for the financing of the proposed SNG s, including access to NRNRs, which, if implemented, may lead to inequality among the SNG s. Although neither constitutional project has yet led to constitutional change, they are both indicative of the type of thinking that would justify a constitutional dispensation that may eventually lead to the advantage of a SNG(s) to the detriment of others. The questions posed in this section are: (a) what are the financial and fiscal measures proposed, including those relating to NRNR s that may result in inequality; (b) what would be the justification of inequality should that materialise; and (c) what may be the likely national responses to these proposals, and eventual constitutional reform outcomes?

\subsection{Solomon Islands}

3.1.1 History and Quest for Constitutional Reform

The Solomon Islands, located in the South Pacific, is a country comprising of nine archipelagos, each currently designated as a province. The population of nearly 600 ooo is mainly Melanesian (95\%) and is scattered across the provinces, with the largest concentrations found on Guadalcanal (141 000) and Malaita (16o ooo) while six provinces have less than 50 ooo inhabitants, with the smallest (Rennell and Bellona) comprising of just over 3 ooo souls. There are over 63 distinct languages, but English is the official language and Solomon Pijin the lingua franca for most. The notion of one nation of Solomon Islanders has been questioned; some argue that they identify themselves more with their island, cultural groups and community than with the nation. ${ }^{32}$ The Islanders are relatively poor, and are mostly involved in subsistence or cash crop farming and less than a third are in paid work. ${ }^{33}$

32 Gordon Nanau, "Unifying the Fragments: Solomon Islands Constitutional Reforms," Development Bulletin - Australian Development Studies Network 6o (January 2002): 4.

33 Solomon Islands Government (SIG), "Solomon Islands: Economic Development Documents - Medium-Term Development Plan, 2016-2o," IMF Country Report, no. 16/91 (March 2016). 
As a political entity, the country emerged first as a declared British protectorate of the southern Solomons in 1893, with further islands being added to the British Administration until 1900. In 1976, the country became self-governing and attained independence in 1978 within the British Commonwealth. ${ }^{34}$ It currently has a centralised system with a very weak provincial system comprising the nine provinces. The main sources of revenue are based on natural resources: fishing, logging and mining, with logging contributing about half of the government's export earnings. Foreign aid is significant, some of which is keenly provided by Taiwan on condition that the government recognises it as a country.

In 1998, tensions arose between residents indigenous to Guadalcanal (which also hosts the capital city of Honiara) and persons hailing from the other islands..$^{35}$ In particular, the inflow of persons from Malaita irked the Gaudalcanalians who claimed that the former dominated the civil service and economy in Honiara. Tensions erupted in 1999 in communal violence on Guadalcanal when persons from Malaita had to flee Guadalcanal. Following a state of emergency, an Australian-led peace-making and -keeping intervention force was invited in 2003 and restored order. Ever since then a solution has been sought to the 'communal tensions' between the different island populations. Federalism has been chief among them. ${ }^{36}$

After the Federal Constitution of Solomon Islands Bill of 2004 found no traction, ${ }^{37}$ a slow process of constitutional reform commenced in 2007 , when a Constitutional Reform Unit was established in the Prime Minister's Office, which spearheaded a constitutional review body. The body comprised the Constitutional Review Congress, which was composed mainly of representatives from the nine provinces, and the Eminent Persons Group, which was appointed by the Prime Minister composed of eminent elders including a former Governor-General. The body worked for ten years and produced a Draft Federal Constitution by June 2018. ${ }^{38}$ At the time of writing, the draft has not yet been debated in Parliament.

34 Nanau, "Unifying the Fragments,".

35 Nanau, "Unifying the Fragments," 11.

36 Nanau, "Unifying the Fragments," 15; Jennifer Corrin, "Breaking the Mould: Constitutional Review in Solomon Islands," Revue Juridique Polynésienne 13 (2007): 143, 167 et seq.

37 For a discussion of the Bill see Corrin, "Breaking the Mould."

38 Milton Ragaruma, "Final Plenary on Draft Federal Constitution Underway," The Island Sun, 31 May 2018, http://theislandsun.com.sb/final-plenary-on-draft-federal-constitutionunderway/. 


\subsubsection{Constitutional Proposals}

The federal project of the draft constitution is animated by two key goals: the first is to ensure equality between the different archipelago states (the former provinces) - equality in services provided by the states themselves. The second goal is to secure significant autonomy of the states, including the maximum possible control by each state over the natural resources of that archipelago and the revenue they may generate. The two goals often prove to be in conflict: the quest for equalisation is based on the notion of the oneness of the nation - the equality of citizenship - which emphasises the sharing of wealth. The goal of autonomy and the quest for control over natural resources (and the inevitable consequence of inequality) sets the interests of individual states and its customary communities before the nation.

On the face of it, then, the quest for a federal Solomon Islands was, in part, driven by the goal of equal outcomes. The debates in the constitution-drafting process were informed by repeated statements about the marginalisation of the islands other than Guadalcanal; the main centre of development has been the capital of Honiara. Not surprisingly for such a small population, all the main state facilities are located in the capital. When the debate came about whether each province should have a High Court, the provincial voices were clear: 'we want our own courts because we are not served by the central High Court'. The underlying premise of the federal compact is thus a common citizenship of a constructed 'nation' with no second-class citizens in geographically located communities. At the same time, the autonomy of each island state is to be secured by strongly entrenched powers in general and fiscal arrangements in particular.

In line with modern constitutional trends, the country is to have three levels of government: federal, state, and community governments. Power is to be divided between the three levels in terms of an extensive list of exclusive federal power, a short list of exclusive state powers, and a broad list of concurrent powers. Key items on the concurrent list fall under federal paramountcy, while the remainder fall under state paramountcy. There is also an extensive list of powers shared by the states and the community governments, the precise division of which is to be regulated by state constitutions.

In neither the exclusive federal list nor in the exclusive state list is mention made of land or natural resources. ${ }^{39}$ In the list of concurrent federal and state jurisdiction with state law paramountcy, the following items are to be found: 'land tenure and dealings', 'land planning, use, management and 
development', 'prospecting for, and mining of, minerals', 'exploration for, and extraction of, hydrocarbons and natural gasses', and 'fisheries'. In the list of state and community concurrent functional areas (with state paramountcy) fall: 'customary land,' 'sea resources and other customary ownership rights', 'tabu sites', 'control and manage the boundaries and ownership of customary land and other resources', and 'logging and fishing.. ${ }^{40}$ The clear inference is that ownership and control resorts under the subnational governments.

The financing of the states is foreseen to be based, in the main, by the sharing of revenue raised or collected by the federal government. The most buoyant taxes are allocated to the federal government; examples are company tax, personal income tax, and goods and sales taxes. ${ }^{41}$ State government taxes include 'mining and prospecting fees', 'land rents', 'state land leases', gaming, liquor licenses, 'foreign investment applications and approval rights', and a bed tax. ${ }^{42}$ Community governments have access to a local business tax and property taxes. With this division, the federal government would raise the bulk of revenue, which must then be shared with the states and community governments in terms of a 'public finance system' which 'must promote a just society', including that 'expenditures must promote the fair and balanced development of the country, including by making special provision for Community Governments and remote areas. 43

The envisaged system of revenue sharing is fairly rigid; specific percentages and a formula are provided for various types of revenue sources. For general revenue, the split is $50 \%$ to the federal government and the rest goes to the states. In the case of personal income tax and sales taxes, the states receive $55 \%$. The split between the nine states is made according to a fix formula: $20 \%$ on an equal basis, $50 \%$ on population size, and $30 \%$ in proportion to the land and sea area of each state. ${ }^{44}$

To address past marginalisation, the revenue necessary for equalisation comes from the federal government's share of the revenue raised nationally. The federal government must ensure, 'in accordance with the recommendations from the National Finance Commission' that:

(a) Each state has the resources to provide comparable levels of services at comparable levels of state taxation; and

\footnotetext{
$40 \quad$ Schedule 5 , list V.

41 Schedule 6, part A.

42 Schedule 6, part B, items 1 and 5 .

43 Clause 176 (1) (b) (ii) Draft Federal Constitution.

44 Schedule 7 , item 1.
} 
(b) State disparities in development and living standards are minimised taking into account the following factors:

(i) Distance from the closest economic hub;

(ii) Existing levels of infrastructure;

(iii) Levels of development according to social indicators;

(iv) Vulnerability to natural disasters including effects of climate change; and

(v) Own capacity to raise revenue. ${ }^{45}$

The reference to 'comparable levels of services at comparable levels of state taxation' combines the principles of equivalence of services, but also the need for state tax effort. It should also be noted that the word 'comparable' is not necessarily the same as 'equal'. Tax capacity refers to states' own efforts to use their taxing powers, not what they may receive from transfers.

Quite separate from the above described financial framework is the regime pertaining to the revenue produced by natural resources. First, "[a]ll revenue derived from natural resource royalties, land lease and those customary in nature are to be paid directly to the resource owners' 46 The resource owners are defined in terms of customary law, the state (federal, state, or community), or private. The territorial domain of ownership is thus important when it comes to offshore resources. The draft Constitution provides very extensive boundaries for states; the entire sea domain of the Solomon Islands state (12 nautical mile territorial waters, and 200 nautical mile Exclusive Economic Zone) is carved up between the nine states, where international boundaries are also those of the island states. The extent of the revenue would then be dependent on definitions of the various types of revenue sources listed.

Secondly, the revenue the federal government may raise from corporate tax, import and export duties, as well as excise duties 'arising from the exploitation of forestry, mining, petroleum, oil, natural gas, agricultural products, marine and non-migratory fisheries, air space and other natural resources' must be shared between the three levels of government as well as with resource owners. The federal government receives $40 \%$, and the rest goes to the State Governments and Community Governments in whose territory the natural resources are located, and 'the tribe, clan, group, family or individual who owns the land or other natural resources, from which the revenue arises. ${ }^{47} \mathrm{The}$ sharing between the state, community governments and resource owners is to be done in accordance with a formula determined in each State Constitution.

45 Schedule 7, part A, item 3, emphasis added.

$46 \quad$ Schedule 7, part B, item 7.

47 Schedule 7, part B, item 8. 
The implications of these provisions are clear: first, as customary ownership of territorial waters would be limited to recognised reefs, the vast expanse of the carved up EEZ would fall within the jurisdiction of the states, and they would be the main beneficiaries of off-shore mining and oil and gas exploitation. Secondly, the revenue derived from natural resources are not to be shared equitably among the states. While a state in which an exploitable natural resource is located should tax such revenue source within its taxing competency (exploration fees, royalties), the major revenue source (corporate and export taxes) would be shared between the federal government and specific oil and gas producing states. When such largesse, such as oil and gas, is discovered and exploited, a high level of inequality may arise between states. The question is then what would politically justify such unevenness in outcomes.

\subsubsection{Inequality and Justification}

The draft Constitution is largely driven by the quest for a recognition of and a return to customary values and practices. In the preamble, the new system will 'recognise the sovereignty of the people and protect the autonomy and interdependence of tribes, clans, lineages, natural family and communities'. Also, first among the values listed in clause $1(2)$ of the draft Constitution is 'respect for our indigenous political units, wisdom, customs, societal values, traditions and governing practices'. The bond between a community and the land they occupy is very strong. Indirectly, when a resource owner seeks to develop a resource on customary land, impact studies must be conducted to 'assess the potential social, spiritual, cultural and environmental impact' of the envisaged development or activity. ${ }^{48}$ The linkage is thus more than seeing a resource in commercial terms, but also that the land fulfils certain social and spiritual functions that define the tribe, clan or community.

The claim to property rights has two legs: the first is restoring the ownership to the indigenous communities, and the second is that it also includes all natural resources found on land. The draft thus provides that '[i]n Solomon Islands, land is to be held, used and managed according with the following principles: (a) recognition and enforcement of customary law in relation to the ownership use of land and natural resources [... and] (c) as far as possible, land is to be restored to the community to which it belonged under the relevant customary law' 49 The meaning of land is extensive: 'all land includes everything

48 Clause 56 (2) (a) Draft Federal Constitution.

49 Clause $5^{2}(1)(a)$ Draft Federal Constitution. 
on, or below the surface of the land down to the centre of the earth, including, in particular, water, petroleum, oil, other minerals and natural gas. ${ }^{50}$

For the islanders, the concept of land is not merely terra firma; the sea adjacent to the island is seen as part of the land. This linkage is commonly expressed as 'the sea is our farm, the reefs and lagoons are our gardens and fields from whence our sustenance comes'. Living off marine resources (narrowly defined) has been an integral part of the communities' way of life. This view of territorial waters, however, undergoes an extension in the draft in two ways. First, the focus is no longer on marine resources, but what lies beneath the seabed, and secondly, the claims of contiguous territorial waters now stretches to the deep sea up to the international borders of the country.

The draft Constitution reflects the views from the various island communities, and the debate with the central government and centrists has yet to commence. Parliament must still debate the draft and holds the key to any constitutional reform. A high level of agreement is required as the 1978 Constitution requires the support of at least three-quarters of the MPs to support the amendment of key provisions (of which the replacement of the Constitution would be one)..$^{51}$ Whether sitting MP s would be interested in effecting radical change is debatable particularly as an important provision in the draft is the abolishment of Constituency Development Funds (CDF) which are doled out to MPs, and have such funds reallocated to the future states. The total CDF budget is currently more than what provinces receive in transfers, and it is the life blood of the Solomon Islands' politics of patronage.

A more important issue would be the agreement among all parties to the establishment of a strong federal system and the possibility of inequality that may flow from the financial arrangements. At the moment, with no real prospects of offshore riches on the horizon, the different island communities may be united in their demand for ownership of the vastly expanded territorial waters, as they all have an even chance to hit the jackpot. If there is a socio-political acceptance of the return to a more customary way of governance, a country comprising of mini-nations each on their own island, a measure of inequality may be seen as inevitable and even celebrated. However, when the riches of the deep emerge for one island and not others, it then becomes a question of the nature and extent of such inequality. Would the claim of the oil-producing state then be questioned as inimical to the national goal of equality, and not supported by customary law's more limited scope of landowners' property

\footnotetext{
$50 \quad$ Clause 53 (2) Draft Federal Constitution.

51 S 61 (2) of the Constitution of 1978.
} 
rights? When that happens the debate on the importance of the unity of the Solomon Islands and the sharing of nature's bounty are bound to resurface.

\subsection{Trinidad and Tobago}

A major reform of the 1976 Trinidad and Tobago Constitution is proposed by Tobago, which would grant this island an elevated autonomy status. The governance of NRNR s would be a component of the new dispensation. Although the current constitutional debate is not about federalism, but about Tobago's autonomy status, the same 'federal question' of equality and inequality, as posed in the Solomon Islands, is present.

\subsubsection{History and Quest for Constitutional Reform}

Trinidad had a long history of various European nations occupying the island since it was sighted by Christopher Columbus in 1498, until the island finally fell under British control in 1801. Tobago became a British Crown Colony only in 1876 which was then joined ten years later with the larger island of Trinidad to form the colony of Trinidad and Tobago, the latter island being the 'ward' of the former. From 1958 to 1962 the nation was part of the West Indies Federation, but with the dissolution of the federation it became independent in August 1962 , and a republic in 1976 in terms of the Constitution of that year. ${ }^{52}$

The differences between the two islands - Trinidad and Tobago - are stark. Trinidad has a land mass of $4828 \mathrm{~km}^{2}$, while Tobago's is only $300 \mathrm{~km}^{2}(4.8 \%$ of the former). The latter's population reflects a similar proportion; of the country's 1.35 million people only 64 ooo reside on Tobago ( $4.7 \%) .{ }^{53}$ The composition of the country's population reflects its colonial past: people of African origin, resulting from centuries of slave trade, comprise $34.2 \%$ of the population, those from Indian origin (indentured labour during British rule) form a slightly higher proportion of $34.4 \%$, and those of mixed origins comprise $23 \%$. The indigenous Amerindians make up a fraction of the population (o.1 \%). ${ }^{54} \mathrm{On}$ Tobago, the vast majority of the population $(87 \%)$ is of African origin.

The country is one of the wealthiest in the Caribbean because of its oil and gas reserves (mostly offshore), accounting for $40 \%$ of its GDP and $80 \%$ of

$5^{2}$ See Richard Drayton, "Whose Constitution? Law, Justice and History in the Caribbean," Sixth Distinguished Jurist Lecture 2016 (Judicial Education Institute of Trinidad and Tobago, 2016).

53 See Government of Trinidad and Tobago's website: http://www.tntisland.com/tnt.html, accessed 1 March 2019.

54 Index Mundi 2018, "Trinidad and Tobago Demographigs Profile 2018", accessed 1 March 2019, https://www.indexmundi.com/trinidad_and_tobago/demographics_profile.html. 
its exports. While Trinidad has the industries flowing from oil and gas, the Tobago economy is based on tourism (more than half of the country's hotel rooms), ${ }^{55}$ fishing, and government spending. In the main, economic development and infrastructure are concentrated on Trinidad, giving rise to claims by Tobagonians of systemic marginalisation.

A year after independence, the first proposal for Tobago's internal selfgovernment was submitted to Parliament. ${ }^{56}$ In 1980 a Tobago House of Assembly was established by statute, granting this body some legislative powers. In 1996 the Constitution was amended to enshrine the Tobago House of Assembly, but its powers were still subject to the direction and control of the Trinidad and Tobago government, thus falling short of internal selfgovernment. ${ }^{57}$ The quest continued with the publication of a Green Paper on the topic in 2013. The process came to a head when Dr Keith Rowley, a Tobagonian, became Prime Minister after the election in 2015 and called upon the Tobagonians to come up with proposals. Leading the process on the island was the Forum of Political Parties of Tobago which conducted extensive consultations. Its proposals were adopted in 2017 by the Tobago House of Assembly, in the form of a Bill amending the 1976 Constitution. ${ }^{58}$ The proposed autonomy status would appear to be a clear expression of Tobagonians' desire for self-government.

In March 2018 the Prime Minister laid the draft Bill - as it was adopted by the THA - before Parliament as the basis for discussion on the way forward. A Joint Standing Committee (JSC), comprising members of both the House of Representatives and the Senate, was tasked to examine the Bill and report back to Parliament by May 2019. By March 2019 the JsC had held three public hearings, receiving evidence and submissions from Tobagonians and government officials and institutions.

3.2.2 Proposals

The two objectives of the Bill - self-government and equalisation between the two islands - are pertinently set out upfront. The 1976 Constitution's

55 See Nations Encyclopedia, "Trinidad and Tobago - Overview of Economy," accessed February 1, 2019, https://www.nationsencyclopedia.com/economies/Americas/Trinidadand-Tobago-OVERVIEW-OF-ECONOMY.html.

$5^{6}$ For an exposition of the quest for internal self-government see the statement to Parliament by Prime Minister Dr Keith Rowley, "The History, Evolution and Current Status of Internal Self-Government for Tobago," March 9, 2018, accessed 1 February 2019, https://www.opm. gov.tt/the-history-evolution-and-current-status-of-internal-self-government-for-tobago/.

57 In the view of Rowley, "The History, Evolution and Current Status."

$5^{8}$ Constitution (Amendment) (Tobago Self-Government) Bill, 2018. 
preamble is to be amended with the following statement: the people of Trinidad and Tobago

[...] recognise the right to self-determination of the people of Trinidad and Tobago including the right of the people of Tobago to determine in Tobago their political status and freely pursue their economic, social and cultural development. ${ }^{59}$

The second objective of equality is expressed as follows:

There shall be equality of status between the Island of Trinidad and the Island of Tobago within the sovereign democratic State of Trinidad and Tobago and the Island of Tobago shall no longer carry the designation of a ward. ${ }^{60}$

Although within the proposed scheme Trinidad would have no separate status, being governed by the Trinidad and Tobago Government (TTG), the sentiment is clear: Tobago's marginalisation can only be measured and corrected with reference to the more prosperous Trinidad.

The question is then how these two objectives are to be pursued simultaneously; are trade-offs to be made to reconcile them? Or would the emphasis on self-government in the end not only ensure equality but also a better standard of living on Tobago? The financial provisions relating to own revenue, revenue derived from non-renewable natural resources, and transfers are key to answering these questions.

While no taxing powers are specifically allocated to Tobago, such powers are located in the general division of powers. Reflecting self-government, the Bill provides for wide legislative powers for the Tobago House of Assembly (Т нA). On the face of it, the THA has an extensive legislative competence over all matters, bar one short list of exclusive TTG functions which includes the following substantive areas: civil aviation, immigration, foreign affairs, judiciary, meteorology, 'National Security (except that internal policing shall be under the jurisdiction of the Tobago Island Government'). ${ }^{61}$ Although it is uncertain whether all matters not mentioned on the list are concurrent powers of both the TTG and Tobago Island Government (TIG), the latter thus has competence over all taxing sources.

\footnotetext{
59 Clause 4 of the Bill.

6o Clause 5 of the Bill.

61 Clause 20 of the Bill, amending Schedule 4 of the Constitution.
} 
Despite the dependence of the economy on oil and gas, these revenue sources are addressed only in a roundabout way. Given the expansive scope of TIG's powers, it would certainly include both the control, management and revenue raising from NRNRs. While there is no reference of taxing or other revenueraising measures relating to oil and gas, the task of sharing the revenue accrued from 'marine resources' is bestowed on the Fiscal Revenue Commission (FRC). This body is envisaged to be an independent intergovernmental body; it has two members appointed by the Tobago Executive Council, and two members by the тTG Cabinet. The fifth member, the chairperson, is appointed by the President at their discretion after consulting the Prime Minister and the Leader of the Opposition. ${ }^{62}$ Although its main task is the vertical division of revenue (discussed below), it must also 'develop a regime for sharing the revenue obtained from marine resources in the waters comprising each island and the maritime boundaries superjacent air space and telecommunications. ${ }^{63}$ Two elements are key to sharing in the revenue of NRNR s: the meaning of 'marine resources' and the jurisdictional area of Tobago. Given that Tobago has jurisdiction over 'such areas of the archipelagic waters of Trinidad and Tobago, including any islands, the seabed and the subsoil, that lies within eleven miles from the low watermark of Tobago', 64 it would follow that marine resources would include oil and gas. The other element is the area of jurisdiction. The Bill states '11 miles', which is slightly less than the 12 miles originally claimed. ${ }^{65}$ As most of the current oil and gas fields lie outside the future Tobago's jurisdiction, the issue is not pertinently dealt with. Nevertheless, some Tobagonians still express the view that the Tobagonian territorial waters should stretch to the median line between Trinidad and Tobago, a distance of 42 nautical miles. ${ }^{66}$

Despite the prospect of wide taxing powers, including those relating to NRNRS, the emphasis of the financing model falls on revenue sharing and transfers. The Bill provides that the annual national budget must include an allocation of 'no less than $8 \%$ of the total sum' of that budget. ${ }^{67}$ The

\footnotetext{
62 Clause $141 \mathrm{AD}(1)$ of the Bill.

63 Clause $141 \mathrm{AD}(3)$ (c) of the Bill.

64 Clause $141 \mathrm{~A}(11)$ of the Bill.

65 The Jsc Chairperson, Camilla Robinson-Regis MP, stated that this was the only change made to the draft Bill on the advice of the Department of Foreign Affairs in the light of international law; Camilla Robinson, "First Public Meeting, JSC," filmed 19 June 2018, accessed 15 February 2019, video, 1 March 2019 https://www.youtube.com/

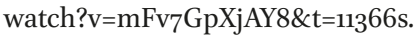

66 Vanus James, "First Public Meeting, JSC," filmed 10 June 2018, accessed 15 February 2019, video, 1 March 2019, https://www.youtube.com/watch?v=mFv7GpXjAY8\&t=11366s. 
actual amount of the transfer could be higher, following the Fiscal Review Commission's recommendations. ${ }^{68}$ This intergovernmental advisory body is tasked to ensure that, in the context of the 'financial and developmental needs of Tobago', the resources be allocated to the island 'as fairly as is practicable'. And in this endeavour, it is to be guided by the following considerations:

(i) physical separation of Tobago by sea from Trinidad;

(ii) isolation from the principal national growth centres;

(iii) absence of the multiplier effect of expenditures and investments (private and public) made in Trinidad;

(iv) restricted opportunities for employment and career fulfilment; and

(v) the impracticability of participation by residents of Tobago in the major educational, cultural and sporting facilities located in Trinidad. ${ }^{69}$

These factors not only explain the causes of inequality between the two islands, but indirectly set out an agenda that goes beyond the equalisation of government services. If Tobago is isolated from 'the principal national growth centres' then the FRC must consider additional transfers in order for the TIG to establish its own growth centres. The recognition of 'restricted opportunities for employment and career fulfilment' in Tobago, should lead to transfers enabling the TIG to develop job opportunities. The overall object is thus more than securing the equalisation of government services, but pointing towards equal economic opportunities and eventually living standards.

The Commission is also mandated to 'ensure that all revenues, fees and duties collected in Trinidad that are attributable to Tobago such as customs duties, import duties and stamp duties shall be held for the account of Tobago.' ${ }^{70}$ If the open-ended phrase 'all revenues, fees and duties' also includes, as it does on the face of it, taxes such as personal income tax or value added tax, it means that the TTG cannot use any of the taxes raised in Tobago even for services it will provide in Tobago.

\subsubsection{Inequality and Justification}

The likely outcome of the financial provisions is that the TIG may in the future have more funds than would otherwise have been the case if equalisation was the only goal. The three sources of revenue - own taxes (unlimited), an entitlement to all tax revenue originating from Tobago but raised by the national government, and a minimum floor of $8 \%$ of the national budget - should result in a financial position that favours Tobago. The likely amount of revenue to

68 Clause $141 \mathrm{AD}(3)$ (a) of the Bill.

69 Clause $14 \mathrm{AD}(3)(\mathrm{f})$ of the Bill.

70 Clause $14 \mathrm{AD}(3)(\mathrm{d})$ of the Bill. 
be collected and received has not yet been calculated. ${ }^{11}$ Similarly, the likely expenditure burden of the TIG as the responsibilities and functions to be performed is not settled at all. Whether there will be more funds flowing into the TIG coffers than are required to ensure equal outcomes (and the elimination of backlogs) in respect of government services, plus equalising living conditions, cannot be said with any measure of certainty. Also, the possible revenue flowing from oil and gas within the territorial jurisdiction of Tobago is to be brought into the equation.

In its public hearings, members of the JSC have raised the spectre of inequality, now with Tobago being better off. The focus of concern was the fixed minimum floor of $8 \%$ of the national budget that should be transferred to the TIG.

JSC members quizzed representatives of Tobago on how $8 \%$ was settled upon. The argument was also raised that Tobago should raise its own resources so that it could be 'economically independent'; the $8 \%$ should simply be transitionary. ${ }^{72}$ It was also pointed out that if the TIG had a surplus of revenue for its expenditure needs, the $8 \%$ transfer would be superfluous; a sunset clause should thus be inserted. Another view was that the percentage should be regularly reviewed. ${ }^{73}$ Although some arguments were put forward as to how the THA arrived at the $8 \%$, it was mostly based on historical patterns of transfers without any reference to the projected new responsibilities and tax sources. The rub of the matter was, as a JSC member pointed out, that TTG may in the future obtain revenue from Tobago if the latter flourishes. ${ }^{74}$

Should any inequality materialise in favour of Tobago, how would such a situation be justified in the union of Trinidad and Tobago? Two possibilities have been suggested: the first is that the goal of self-government is bounded up in past neglect and marginalisation, which requires compensation. The second, only tangentially argued, is that the Tobagonians are a separate nation. As such, the wealth of the island (and the territorial waters around) belong to them. In the public hearings, a Tobagonian argued for the 'need of a contract

71 The Deputy Governor of the Central Bank of Trinidad and Tobago, Sandra Sookram, conceded that such estimates have yet to be made; Sandra Sookram, "Third Public Meeting, JSC," filmed 8 February 2019, accessed 1 March 2019, video, https://www.youtube.com/ watch?v=8kYjFcTSvoA.

72 "First Public Meeting, JSC," filmed 10 June 2018, accessed 15 February 2019, video, https:// www.youtube.com/watch? $=m$ Fv7 GpXjAY8\& $=11366 \mathrm{~s}$.

73 “Third Public Meeting, JSc," filmed 8 February 2019, accessed 1 March 2019, video, https:// www.youtube.com/watch? $\mathrm{v}=8 \mathrm{kYjFcTSvoA}$.

74 Terence Deyalsingh MP, "Third Public Meeting, Jsc," filmed 8 February 2019, accessed 1 March 2019, video, https://www.youtube.com/watch?v=8kYjFcTSvoA. 
between both nations [Trinidadians and Tobagonians]', calling the 1888 act of union 'a disaster'.75 The JSC's chairperson immediately reacted, proclaiming that there is only one nation, that of Trinidad and Tobago. Moreover, there was no definition of a Tobagonian other than any person living on Tobago. ${ }^{76}$ No claims to ancestral lands are made. Although the majority of the population on Tobago are of African heritage, no claims to the island based on origin have been made.

The demand for Tobago autonomy has not spilled over in conflict but is a slow process of increasing political pressure that is finding traction in the current political discourse of the country. Little direct attention is given to NRNRS in the autonomy claims, despite the fact that oil and gas are major resources. This is partially explained by the fact that the oil and gas fields fall mostly outside the claimed Tobago jurisdiction. Yet, with an expansive scope of powers, the TIG would have substantive control over oil and gas found in its claimed jurisdiction. The immediate Tobagonian concern is accessing the revenue raised nationally from these resources. Pinning the share of revenue at a fixed $8 \%$ is likely to meet considerable opposition precisely because of a prospect of future inequality. Quite different from the island claims in the Solomon Islands, a preferential treatment of Tobago would likely be confined to rectifying past marginalisation and underdevelopment. The case for a possible economically elevated position for Tobago seems at present unlikely to be accepted by the majority of the population.

\section{$4 \quad$ Concluding Remarks}

In the Solomon Islands and Trinidad and Tobago, the quest for non-centralism has been a slow process, coming to some sort of fruition in the form of draft constitutions (or amendments) at more or less the same time. The proponents of self-government for island communities have produced remarkably similar constitutional proposals, although the political processes in the two countries bore no knowledge of one another. Although the ownership, control and revenue of NRNRS are approached differently, the results are uncannily similar. Whether the two sets of proposals will eventually find constitutional entrenchment, and if so, in what form, it is too early to say.

\footnotetext{
75 Anthony Hector, "First Public Meeting, Jsc," filmed 10 June 2018, accessed 15 February 2019, video, https://www.youtube.com/watch?v=mFv7GpXjAY8\&t=11366s.

76 Foster Cummings MP, "First Public Meeting, JSC," filmed 10 June 2018, accessed 15 February 2019, video, https://www.youtube.com/watch?v=mFv7GpXjAY8\&t=11366s.
} 
In both sets of constitutional proposals, the twin goals of self-government and solidarity are pursued. In both cases a sense of marginalisation is the wellspring for these goals. In the Solomon Islands the quest is also tied up with an attempt to return to custom and tradition of old. In both cases, the financial claims are likely to be to the advantage of some islands in the Solomon Islands and Tobago, with inequality the likely outcome.

Similarities in the claims relating to access to financial resources abound. First, taxing powers of the subnational governments are substantial. For Tobago, there are no constitutional limits to the range of taxing powers the island government would exercise. In the Solomon Islands the subnational taxing powers are clearly listed, but are still substantial.

Secondly, in both cases priority access to the wealth of NRNR $s$ is assured. In the draft Solomon Constitution subnational claims are directly aimed at the control and benefit of NRNR s, which are bolstered by an expansive definition of the states' jurisdiction which goes beyond a narrow definition of territorial waters, to the country's exclusive economic zone. In the Tobago Bill, only indirect claims are made with regard to NRNR s; ownership, control and benefit of NRNR $s$ would fall within the Tobago's almost unlimited powers. The claim to the seabed and the subsoil is more modest, stretching only to 11 nautical miles territorial waters.

Thirdly, the stated goal of equalisation in government services in both countries is pursued through substantial claims to revenue raised nationally. High percentages are set in the Solomon Islands, depending on the revenue source, which overall would be more than $50 \%$ of the national budget. In the case of Trinidad, the percentage is eight.

In both countries the financial arrangements will more than likely lead to inequality; in the case of the Solomon Islands, among the future states, and in Tobago, greater per capita state expenditure than in Trinidad as well as on equal economic opportunities. The questions are then, first, how such inequality is to be justified by the claimants, and secondly, the acceptability in the broader body politic of such justifications.

The justification of any inequality among the island states of the Solomon Islands is closely tied to the unarticulated notion of separate 'nations', but expressed in terms of strong self-government. The 'nation' claims are expressed through the exultation of the custom and tradition of island communities and their return, recognising their historical claims to land and the adjacent sea. It highlights the artificial clumping together of the 'nation' of Solomon Islanders by the British in the 19th century for administrative convenience. Future inequality would thus simply be a consequence of ownership of land and sea which should be returned to the rightful owners in terms of customary 
law. A level of inequality may thus be tolerated by the island polities based on a shared vision of communities owning resources, accepting the eventuality that only some islands may be resource-rich.

In contrast, the claims of the Tobagonians are based on past neglect and marginalisation, not ownership. Equality is the overall goal and claiming ownership rights by a 'nation' of Tobagonians is weak. There are no historical claims of indigenous people as Tobagonians are defined as such simply by reference to residency. While there seems to be acceptance in principle by Trinidadians that corrective action should be taken, any notion of a separate 'Tobago nation', with historical property rights, is not being entertained. The placing of Tobagonians in a better position than their compatriots in Trinidad is not likely to be accepted. Thus, the claim for a fixed $8 \%$ of the national budget, which may result in such an advantage, is under close scrutiny.

How the contradiction between the need for equality and the demand for self-government which may result in advantage to producing regions vis-àvis the others, can be sustained (or legitimated), lies in the particular political and social norms and culture of a country. Levels of inequality which would be unpalatable in one country, may be acceptable in another. The theoretical underpinning of the equalisation of service outcomes and economic opportunities is usually the assertion of the oneness of the nation; in a diverse society every citizen, no matter where they are located, should enjoy the benefits of equal citizenship. The reasoning behind the unequal benefit from NRNR s, is based on ownership claims where the oneness of the nation (or nation building) is not the primary goal, but the well-being of individual regions takes centre stage. There may also be other reasons for levels of inequality to be tolerated, such as a specific subnational government's perceived position of strength. There is no formula to determine the balance between self-government and national solidarity; achieving the right balance lies in the hands of the negotiating parties. At their disposal are the flexible tools in the federalism toolbox which one hopes they will use judiciously, by not allowing the manner in which NRNR s are dealt with to be the cause of future conflicts.

\section{Bibliography}

Ahmad, Ehitisham and Giorgio Brosio. "Can Lessons from Equalisation Transfers in Industrialised Countries be Applied to Reforms in Emerging-Market Countries?" In Comparing Fiscal Federalism, edited by Alice Valdesalici and Francsco Palermo, 169-189. The Hague: Brill/Nijhoff, 2018. 
Alber, Elizabeth. "Intergovernmental Financial Relations: Institutions, Rules and Praxis." In Comparing Fiscal Federalism, edited by Alice Valdesalici and Francesco Palermo, 223-273. The Hague: Brill/Nijhoff, 2018.

Ayele, Zemelak Ayitenew. "Constitutionalism: The Missing Element in South Sudan's Elusive Quest for Peace through Federalism?." In Decentralisation and Constitutionalism in Africa, edited by Charles Fombad and Nico Steytler, 234-254. Oxford: Oxford University Press, 2019.

Bauer, Andrew, Uyanga Gankhuyag, Sofi Halling, David Manley and Varsha Venugopal. Natural Resource Revenue Sharing. Natural Resource Governance Institute (NRGI) and the United Nations Development Programme (UNDP), 2016.

Brosio, Giorgio and Raju Jan Singh. "Raising and Sharing Revenues from Natural Resources: A Review of Country Practices." Discussion Paper, MFM Global Practice, no. 5 (August 2015).

Corrin, Jennifer. "Breaking the Mould: Constitutional Review in Solomon Islands." Revue Juridique Polynésienne 13 (2007): 143-168.

Cummings, Foster. "First Public Meeting, JSC." Filmed June 10, 2018, accessed February

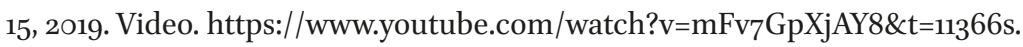

Deyalsingh, Terence. “Third Public Meeting, JSC.” Filmed February 8, 2019, accessed March 1, 2019. Video. https://www.youtube.com/watch?v=8kYjFcTSvoA.

Drayton, Richard. "Whose Constitution? Law, Justice and History in the Caribbean." Sixth Distinguished Jurist Lecture 2016. Judicial Education Institute of Trinidad and Tobago, 2016.

Forum of Federations. "Oil and Gas in Federal Systems." forumfed.org (2014). https:// www.shareweb.ch/site/DDLGN/Documents/OIL\%2O_\%2OGAS\%2oin\%2ofederal\%2ocountries\%20(2014)_G\%2oAnderson.pdf.

Haysom, Nicholas and Sean Kane. "Negotiating Natural Resources for Peace:Ownership, Control and Wealth Sharing." Briefing Paper (October 2009). http://comparativeconstitutionsproject.org/files/resources_peace.pdf.

Hector, Anthony. "First Public Meeting, JSC." Filmed June 10, 2018, accessed February

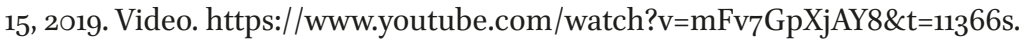

James, Vanus. "First Public Meeting, JSC." Filmed June 10, 2018, accessed February 15, 2019. Video. https://www.youtube.com/watch?v=mFv7GpXjAY8\&t=11366s.

JSC. “First Public Meeting, JSC.” Filmed June 10, 2018, accessed February 15, 2019. Video,. https://www.youtube.com/watch?v=mFv7GpXjAY8\&t=11366s.

JSC. "Third Public Meeting, JSC." Filmed February 8, 2019, accessed March 1, 2019. Video. https://www.youtube.com/watch?v=8kYjFcTSvoA.

Lecours, André and Daniel Béland. "Federalism and Fiscal Policy: The Politics of Equalization in Canada." Publius: The Journal of Federalism 40, no. 4 (Autumn 2010): $569-596$. 
Nanau, Gordon. "Unifying the Fragments: Solomon Islands Constitutional Reforms." Development Bulletin - Australian Development Studies Network 6o (January 2002): 17-20.

Nations Encyclopedia. "Trinidad and Tobago - Overview of Economy." Accessed February 1, 2019. https://www.nationsencyclopedia.com/economies/Americas/ Trinidad-and-Tobago-OVERVIEW-OF-ECONOMY.html.

Ragaruma, Milton. "Final Plenary on Draft Federal Constitution Underway." The Island Sun, May 31, 2018. http://theislandsun.com.sb/final-plenary-on-draft-federal-constitution-underway/.

Robinson, Camilla. "First Public Meeting, JSC." Filmed June 10, 2018, accessed February

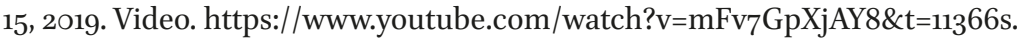

Rowley, Keith. "The History, Evolution and Current Status of Internal Self-Government for Tobago." March 9, 2018, accessed February 1, 2019. https://www.opm.gov.tt/thehistory-evolution-and-current-status-of-internal-self-government-for-tobago/.

Solomon Islands Government (SIG). "Solomon Islands: Economic Development Documents - Medium-Term Development Plan, 2016-20." IMF Country Report, no. 16/91 (March 2016).

Sookram, Sandra. "Third Public Meeting, JSC." Filmed February 8, 2019, accessed March 1, 2019. Video. https://www.youtube.com/watch?v=8kYjFcTSvoA.

Wanyande, Peter. "Devolution and Territorial Development Inequalities: The Kenyan Experience." Working Paper Series, no. 187 (2016). 